\title{
RESENHA
}

\section{MEMÓRIAS DOCENTES, RECORDAÇÕES DISCENTES: UM PASSADO SOB OS OLHOS DO TEMPO PRESENTE}

\author{
Mariane Martins \\ Universidade do Estado de Santa Catarina, Brasil
}

$\cos 80$

DA SILVA, Vera Lucia Gaspar; SCHÜEROFF, Dilce. Memória docente: histórias de professores catarinenses (1890-1950). Florianópolis: Udesc, 2010.

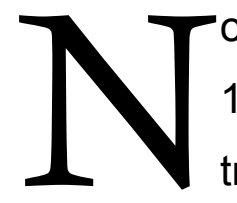

o livro Memória docente: histórias de professores catarinenses (18901950), as organizadoras, Vera Lucia Gaspar da Silva e Dilce Schüeroff, transcrevem memórias de professores entendidas como singulares por serem constituídas ao longo da vida escolar em Santa Catarina. A obra foi publicada em 2010 pela editora da Udesc e é resultado do projeto de pesquisa Memória docente: histórias de professores catarinenses (1890-1950).

O livro é constituído pela transcrição de vinte e três relatos ou entrevistas de homens e mulheres que, hoje aposentados, exerceram o ofício de professores em escolas de diversas regiões de Santa Catarina.

Nas Primeiras notas (p. 25), as organizadoras detalham sobre os anos à espera de recursos para a publicação do material e também explicam as razões que as instigaram a 
realizar e publicar a pesquisa. Dentre os motivos citados estão a importância dessas memórias para a história da educação e da profissão docente para Santa Catarina.

Os relatos são apresentados em forma de narrativas e apresentados em três momentos: Vida privada, A escola e Atuação profissional/docência e abordam os castigos, as brincadeiras, o uniforme, o ingresso como professores, a higiene e saúde na escola, as dificuldades, as disciplinas, a metodologia, a ação dos inspetores, as comemorações cívicas e a aposentadoria.

Além desses assuntos mereceu atenção o tema material didático, que se mostra, nos relatos, rico em informações. Ao longo dos vinte três relatos, muitos dos entrevistados citaram a cartilha que denominavam como cartilha do boi, assim chamada porque "na primeira lição tinha um boi, por isso o nome" (Aida Rosa, 1994). Alguns dos entrevistados citam o autor da cartilha, "Eu me lembro de muitas leituras do nosso livro do primeiro ano que foi elaborado pelo nosso saudoso professor Henrique da Silva Fontes ${ }^{1}$, pessoa realmente extraordinária" (Januário Serpa, 1994).

Essa cartilha, de acordo com Da Silva e Flores (2010), foi uma coleção distribuída gratuitamente na rede de instrução pública de Santa Catarina e utilizada em escolas de ensino privado entre as décadas de 1920 e 1950. A Série Fontes, como ficou conhecida, era constituída por cinco cartilhas: Cartilha popular, Primeiro, Segundo, Terceiro e Quarto livros de leitura. Desta série, outra cartilha também mencionada no livro é o Primeiro livro de leitura, lembrada pelos entrevistados pelo tema da primeira lição: "Lembro da cartilha do Henrique Fontes. Era muito boa. Lembro até de certas partes. A primeira lição era "o trabalho". Sabia, bem até pouco tempo, mas de repente a gente esquece" (Eugênia Pires, 1999). Outro material lembrado é a lousa. Quando referida, nota-se que os professores descrevem com muitos detalhes a maneira de manuseá-la e as dificuldades em estudar por meio dela.

Nas memórias de professores, os materiais didáticos citados são diversificados e pouco detalhados, quando comparado com as memórias de quando alunos. Alguns citam o computador, slide, televisão, mas enfatizam que isso ocorre dentro das possibilidades da escola. Não há, nesse segundo momento, um material que se sobressaia.

Observa-se que os relatos são mais esmiuçados e as histórias mais animadas quando os entrevistados falam de sua vida escolar como estudante. Ocorre o oposto quando falam de sua vida como professor: algumas memórias demonstram desânimo, mais seriedade, cansaço, talvez desesperança.

\footnotetext{
${ }^{1}$ Henrique da Silva Fontes nasceu em 1885 e faleceu em 1966. De 1911 a 1918 exerceu a função de chefe da Instrução Pública do município de Florianópolis. Ver http://www.henriquefontes.pro.br.
} 
Converter as memórias de alguém em palavras e trabalhá-las é uma função que merece cautela e atenção. Os sentimentos tornam-se mais intensos e podem interferir nas lembranças relatadas. Em todo o livro, em cada relato, há um comentário, breve ou extenso, onde o "naquele tempo", o passado, e o "hoje em dia", o presente, são confrontados. No geral, o "naquele tempo" é exaltado: "naquela época o professor exigia e era atendido" (p. 66), "[hoje] não respeitam [os alunos] o professor" (p. 91), "antigamente era rígido" (p. 118), "hoje em dia [as comemorações cívicas] é um do lado do outro conversando" (p. 122).

A memória das pessoas, seja como estudantes, seja como professores, permite aprofundar, com um olhar do tempo presente, a vida escolar, as mudanças ocorridas ao longo dos anos e o contexto de cada época. O livro se reveste de importância para os estudos da história da educação catarinense e brasileira, não apenas por expor as memórias de docentes com a simples finalidade de não ser esquecido, mas para utilizá-lo como um documento que permite futuras pesquisas cotejadas com outras fontes e com o olhar do tempo presente.

\section{Referências}

DA SILVA, Cristiani Bereta; FLORES, Maria Bernardete Ramos. Gênero e nação: a Série Fontes e a virilização da raça. Disponível em: <http://www.sumarios.org/sites/default/files/pdfs/64394 7294.PDF>. Acesso em: 22 fev. 2012.

PIRES, Eugênia de Oliveira Nunes. Entrevista a Alessandra Zocoli Borges. Florianópolis, 17 jun. 1999.

ROSA, Aida Pereira da. Entrevista a Rosinei da Silveira. Imbituba, 5 mar. 1994.

SERPA, Januário Raimundo. Entrevista a Rosinei da Silveira. Florianópolis, 31 ago. 1994.

MARIANE MARTINS é estudante do curso de História da Universidade do Estado de Santa Catarina - Udesc.

Endereço: Rua Abelardo Otacílio Gomes, 33A - 88067-970 - Florianópolis - SC Brasil.

E-mail: marianeh3@hotmail.com.

Recebido em 4 de abril de 2012.

Aceito em 25 de junho de 2012. 